\title{
NEUROPROTECTIVE AND ANTIAPOPTOTIC POTENTIAL OF TRIGONELLINE IN A STRIATAL 6-HYDROXYDOPAMINE RAT MODEL OF PARKINSON'S DISEASE
}

\author{
Received July 28, 2014
}

Considering neuroprotective and antioxidant effects of trigonelline, our study was undertaken to evaluate its protective effect in a 6-hydroxydopamine-induced model of Parkinson's disease $(\mathrm{PD})$ in rats. Unilateral intrastriatal 6-OHDA-lesioned rats were pretreated with trigonelline at doses of 50 and $100 \mathrm{mg} / \mathrm{kg}$. Significant rotational behavior, a significant reduction in the number of Nissl-stained neurons on the left side of substantia nigra pars compacta (SNC), increased apoptosis, enhanced levels of malondialdehyde (MDA) and nitrite, and a lower level of glutathione (GSH) were observed in 6-OHDA-lesioned rats. Trigonelline at a dose of $100 \mathrm{mg} / \mathrm{kg}$ significantly reduced rotations, prevented reduction of SNC neurons, prevented apoptosis, and restored the MDA level. These results suggest that pre-lesion trigonelline treatment exerts dose-dependent neuroprotective and antiapoptotic effects under conditions of 6-OHDA toxicity and may be, henceforth, advantageous for the management of early PD.

Keywords: Parkinson's disease, trigonelline, 6-hydroxydopamine, apoptosis, oxidative stress.

\section{INTRODUCTION}

Parkinson's disease (PD) is a rather widespread neurodegenerative disorder with such cardinal clinical symptoms as bradykinesia, rigidity, resting-state tremor, postural imbalance, and gait impairment [1]. These motor disabilities inevitably lead to a lower quality of life [2]. The global occurrence of PD is about $0.3 \%$ in the general population and $1-2 \%$ in subjects elder than 60-65 years [2]. Behavioral and cognitive problems, including dementia, depression, anxiety, and sleep disturbances, also appear within late stages of PD $[3,4]$. At present, treatment for PD includes mainly symptomatics and usually starts with Levodopa and/or dopamine agonists [5]. Nevertheless, after some time, most PD patients experience side effects, including motor and nonmotor fluctuations and dyskinesia [6].

Oxidative stress-mediated neuronal death plays a key role in the pathogenesis of PD [7]. A neurotoxin, 6-hydroxydopamine (6-OHDA), is routinely used to

\footnotetext{
${ }^{1,2}$ Shahed University, Tehran, Iran

( ${ }^{1}$ Neurophysiology Research Center; ${ }^{2}$ Student Research Committee). Correspondence should be addressed to M. Roghani (mehjour@yahoo.com).
}

damage mesencephalic dopaminergic neurons and to yield a widely used animal model of PD [8]. Because environmental factors are engaged in the majority of PD cases, it is important to assess the effectiveness of natural products in neuroprotective interventions for PD [9]. Meanwhile, patients with PD often turn to complementary and alternative medicine [10].

The alkaloid trigonelline ( $\mathrm{N}$-methylnicotinic acid) is a metabolite of nicotinic acid. It is mainly found in fenugreek seeds and coffee beans. Trigonelline demonstrates a potent antioxidant property and strong free-radical scavenging activity $[11,12]$. This agent was shown to attenuate diabetes-induced auditory neuropathy [13] and was, in general, reported to induce neurite outgrowth and reconstruction of neuronal networks in the damaged brain, which is exclusively important for the therapeutic treatment of neurodegenerative diseases [14]. In addition, a standardized extract of fenugreek seeds, which contain high amounts of trigonelline, was capable of reversing motor dysfunction in rats with 6-OHDA-induced unilateral cerebral lesion [15]. For these reasons, trigonelline may be regarded as a prospective effective mean against PD. Our study was undertaken to assess the possible neuroprotective potential of pre-lesion trigonelline treatment in the 6-OHDA-induced early model of PD in rats. 


\section{METHODS}

Chemicals and Reagents. Trigonelline, 6-OHDA, apomorphine, Cresyl violet, and oxidative stress kits were obtained from Sigma-Aldrich (Germany). All other chemicals were procured by Merck (Germany).

Animals. Adult male Wistar rats $(180-210 \mathrm{~g}, n=60)$ were provided by the Pasteur's Institute (Tehran, Iran). The animals were housed in a temperature-controlled colony room under $12 / 12 \mathrm{~h} \mathrm{light/dark}$ cycle with free access to food and water and held in the above room for at least one week before being tested. Only rats showing no rotational behavior (net rotations less frequent than $30 \mathrm{~h}^{-1}$ ) were subjected to i.p. injections of apomorphine hydrochloride $(2 \mathrm{mg} / \mathrm{kg})$ in our study. The animals were randomly divided into five groups: (i) shamoperated; (ii) sham-operated + trigonelline(100); (iii) 6-OHDA-lesioned; (iv) lesioned + trigonelline(50), and (v) lesioned + trigonelline(100; see below). Stereotaxic unilateral intrastriatal 6-OHDA injections (left side) were performed using a $5 \mu$ Hamilton syringe into anesthetized rats (ketamine $80 \mathrm{mg} / \mathrm{kg}$ and xylazine $10 \mathrm{mg} / \mathrm{kg}$, i.p.). A stereotaxic apparatus (Stoelting, USA) was used (coordinates: $\mathrm{L}-3 \mathrm{~mm}, \mathrm{AP}+9.2 \mathrm{~mm}$, and $\mathrm{V}+5 \mathrm{~mm}$ from the center of the interaural line, according to the atlas of Paxinos and Watson [16]). After injection, the needle was left in place for an additional $5 \mathrm{~min}$ and then withdrawn at a rate of $1 \mathrm{~mm} / \mathrm{min}$. The lesioned groups received single injections of $2.5 \mu \mathrm{g} / \mu \mathrm{l}$ of 6 -hydroxydopamine$\mathrm{HCl}$ in $5 \mu \mathrm{l}$ of $0.9 \%$ saline containing $0.2 \%$ ascorbic acid $(\mathrm{w} / \mathrm{v})$ at a rate of $1 \mu \mathrm{l} / \mathrm{min}$. The sham group received an identical volume of the ascorbate-saline solution. The 6-OHDA+trigonelline(50) and 6-OHDA+trigonelline (100) groups received the neurotoxin in addition to trigonelline i.p. dissolved in normal saline at doses of 50 and $100 \mathrm{mg} / \mathrm{kg}$. Trigonelline was daily administered three times before the surgery, with the last injection made $1 \mathrm{~h}$ pre-surgery. The doses of trigonelline were chosen according to our preliminary study.

Behavioral Evaluation. The animals ( $n=9$ in each group) were tested for apomorphine hydrochloride ( $2 \mathrm{mg} / \mathrm{kg}$, i.p.)-induced rotational behavior one week before surgery (baseline) and at 1 st week post-surgery. The rotations were measured according to a method described previously [8]. Briefly, the animals were allowed to habituate for $10 \mathrm{~min}$; then, $1 \mathrm{~min}$ after the injection, full rotations were counted in a cylindrical container (diameter $33 \mathrm{~cm}$ and height $35 \mathrm{~cm}$ ) within 10-min-long intervals for $60 \mathrm{~min}$ (in a dimly-lighted and quiet room). Net number of rotations was defined as the positive score minus the negative score.
Assessment of Oxidative Stress. Midbrain samples ( $n=5$ for each group) were dissected from the rat brains and washed-off in cold normal saline. Their anterior one-thirds were blotted dry, weighed, homogenized ( $5 \%$ of tissue) in ice-cold normal saline, and centrifuged at $4{ }^{\circ} \mathrm{C}$. The obtained supernatant was aliquotted and stored at $-70^{\circ} \mathrm{C}$ until being assayed.

Estimation of the MDA Content in the Midbrain. The malondialdehyde (MDA) concentration (thiobarbituric acid reactive substances, TBARS) in the supernatant was measured as described before [8]. Briefly, trichloroacetic acid and a TBARS reagent were added to the supernatant, then mixed, and incubated at boiling water for $90 \mathrm{~min}$. After cooling on ice, the samples were centrifuged at $1000 \mathrm{~g}$ for $10 \mathrm{~min}$, and the absorbance of the supernatant was read at $532 \mathrm{~nm}$. The TBARS results were expressed as MDA equivalents using tetraethoxypropane as the standard.

Midbrain Nitrite Assay. The nitrite content in the supernatant was assayed by the Griess method according to previous studies [17]. Because NO is a compound with a short half-life and is rapidly converted into stable end products, nitrate $\left(\mathrm{NO}_{3}^{-}\right)$and nitrite $\left(\mathrm{NO}_{2}^{-}\right)$, the principle of the assay is the conversion of nitrate into nitrite by cadmium. This is followed by color development with the Griess reagent (containing sulfanilamide and N-naphthyl ethylenediamine) in an acidic medium. The total nitrite was measured by Griess reaction. The absorbance was measured at $540 \mathrm{~nm}$ with a spectrophotometer.

Catalase Activity Asssay. For this purpose, the Claiborne's method was used [18]. Briefly, $\mathrm{H}_{2} \mathrm{O}_{2}$ was added to a mixture of $50 \mathrm{mM}$ potassium phosphate buffer $(\mathrm{pH}$ 7.0) and supernatant, and the rate of $\mathrm{H}_{2} \mathrm{O}_{2}$ decomposition was assessed by measuring the absorbance changes at $240 \mathrm{~nm}$ for $2 \mathrm{~min}$. One unit of the catalase activity was defined as $1.0 \mu \mathrm{mol}$ of $\mathrm{H}_{2} \mathrm{O}_{2}$ decomposed within $1 \mathrm{~min}$.

Measurement of the Reduced Glutathione (GSH) Level. The GSH level was measured spectrophotometrically as described before [19, 20]. Briefly, the supernatant was centrifuged with $5 \%$ trichloroacetic acid, to centrifuge out the proteins. Two milliliters of phosphate buffer ( $\mathrm{pH} 8.4), 0.5 \mathrm{ml}$ of 5'5 dithiobis (2-nitrobenzoic acid, DTNB), and $0.4 \mathrm{ml}$ of bidistilled water were added to $0.1 \mathrm{ml}$ of the homogenate. The mixture was vortexed, and the absorbance was read at $412 \mathrm{~nm}$ within $15 \mathrm{~min}$.

Protein Assay. The protein content in the supernatant was measured with the Bradford method using bovine serum albumin as the standard [21]. 
Estimation of DNA Fragmentation (Apoptosis). In this experiment, three rats from each group were euthanized one day after intrastriatal 6-OHDA injection, and the midbrain tissue supernatant was prepared as above-mentioned. The determination of histoneassociated DNA fragments was performed using the Cell Death Detection ELISA kit (Roche Diagnostics, Germany) as an indicator of apoptosis according to the protocol from the company and the procedure as described before [22]. The assay is based on a quantitative sandwich-enzyme-immunoassay principle using mouse monoclonal antibodies directed against DNA and histones, respectively. This allows the specific determination of mono- and oligonucleosomes (histoneassociated DNA fragments) in the fraction of tissue lysates. The amount of nucleosomes demonstrating DNA degradation was quantified by peroxidase retained in the immunocomplex. The peroxidase content was determined photometrically at $405 \mathrm{~nm}$ with 2,2 ' -azinobis(3-ethylbenzothiazoline-6-sulphonic acid) as a substrate by a microplate reader (BioTek, USA) after $15 \mathrm{~min}$ of the substrate reaction time. The results were expressed as the optical density (OD).

Histochemistry. At the end of the study, the rats ( $n=4$ for each group) were deeply anesthetized with a high dose of ketamine $(150 \mathrm{mg} / \mathrm{kg})$ and perfused through the ascending aorta with $50-100 \mathrm{ml}$ of $0.9 \%$ saline followed by $100-150 \mathrm{ml}$ of the fixative solution containing $4 \%$ paraformaldehyde in $0.1 \mathrm{M}$ phosphate buffer (PB, pH 7.4) followed by $100 \mathrm{ml}$ of $0.1 \mathrm{M}$ PB. After perfusion, the brains were removed from the skull; blocks of the forebrain and brainstem were prepared, and, after final steps of preparation (immersion in $30 \%$ sucrose solution for 1-2 days), 30-mm-thick sections were cut on a freezing microtome and collected in PB $(0.1 \mathrm{M})$. Every second section was Nissl-stained with $0.1 \%$ cresyl violet.

Histology. For each animal, mesencephalic sections (interaural 2.9-4.2 $\mathrm{mm}$ ) were examined by a method described previously [7]. Nissl-stained neurons in the SNC were manually counted (light microscopy, $\times 400$ ) using a superimposed grid to facilitate the procedure. At least two sections representative of each of four Paxinos-Watson planes (4.2, 3.7, 3.2, 2.97, interaural) were examined by scanning the entire extent. Counting was done blind to the treatments received.

Statistical Analysis. All data are expressed as means \pm s.e.m. For statistical evaluation of the data, the parametric one-way ANOVA followed by the Tukey's post-hoc test was used. In all analyses, the null hypothesis was rejected at $P<0.05$.

\section{RESULTS}

The beneficial effect of trigonelline at doses of 50 and $100 \mathrm{mg} / \mathrm{kg}$ was evaluated according to apomorphineinduced rotations for a period of $1 \mathrm{~h}$ (Fig. 1). There were no significant differences among the groups at baseline (before surgery). Statistical analysis of the total net number of rotations at the first week post-surgery showed that apomorphine injections caused a very significant contralateral turning in the rats of the 6-OHDA-lesioned group $(P<0.001)$ and induced significant but less intense rotations in the 6-OHDA+trigonelline $(50)(P<0.005)$ and 6-OHDA+trigonelline(100) groups $(P<0.01)$ in comparison with the sham group. Moreover, the group 6-OHDA+trigonelline(100) showed a significantly smaller number of rotations $(P<0.05)$ when compared to 6-OHDA-lesioned rats.

$A$
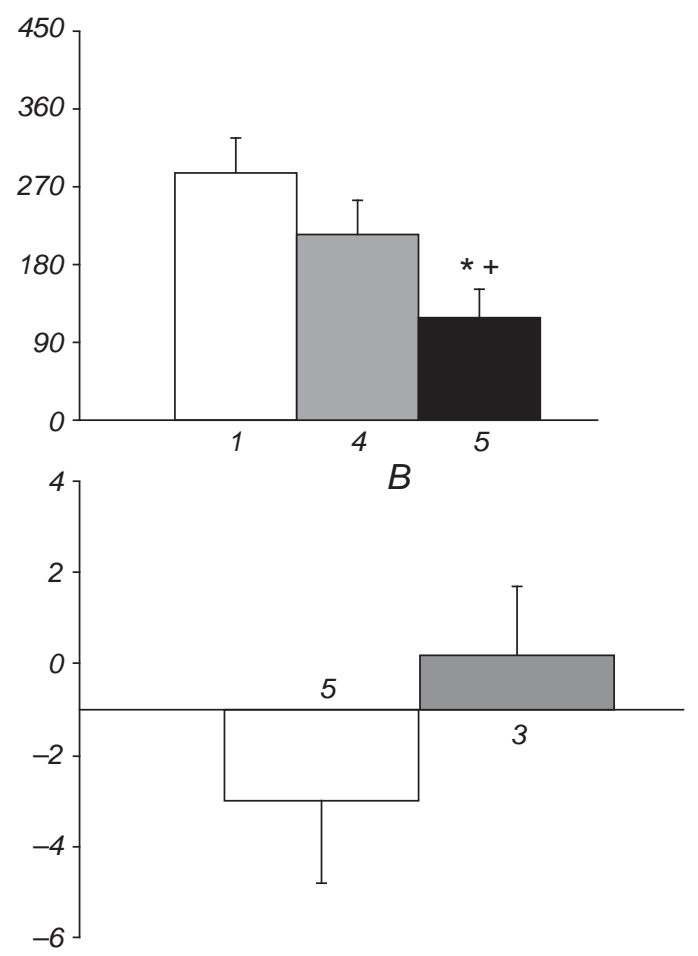

F i g. 1: Numbers of apomorphine-induced rotations (within a 1-h-long observation period) in different groups (A) and decrement/ increment of this index in 6-OHDA-lesioned groups (B). 1-5 are indications of the experimental groups (see Methods). ${ }^{*} P<0.05$ in comparison with the control group; ${ }^{+} P<0.05$ in comparison of groups 4 and 5 .

P и с. 1. Інтенсивність викликаної апоморфіном обертальної моторної активності в моделі хвороби Паркінсона, індукованій 6-OHDA. 

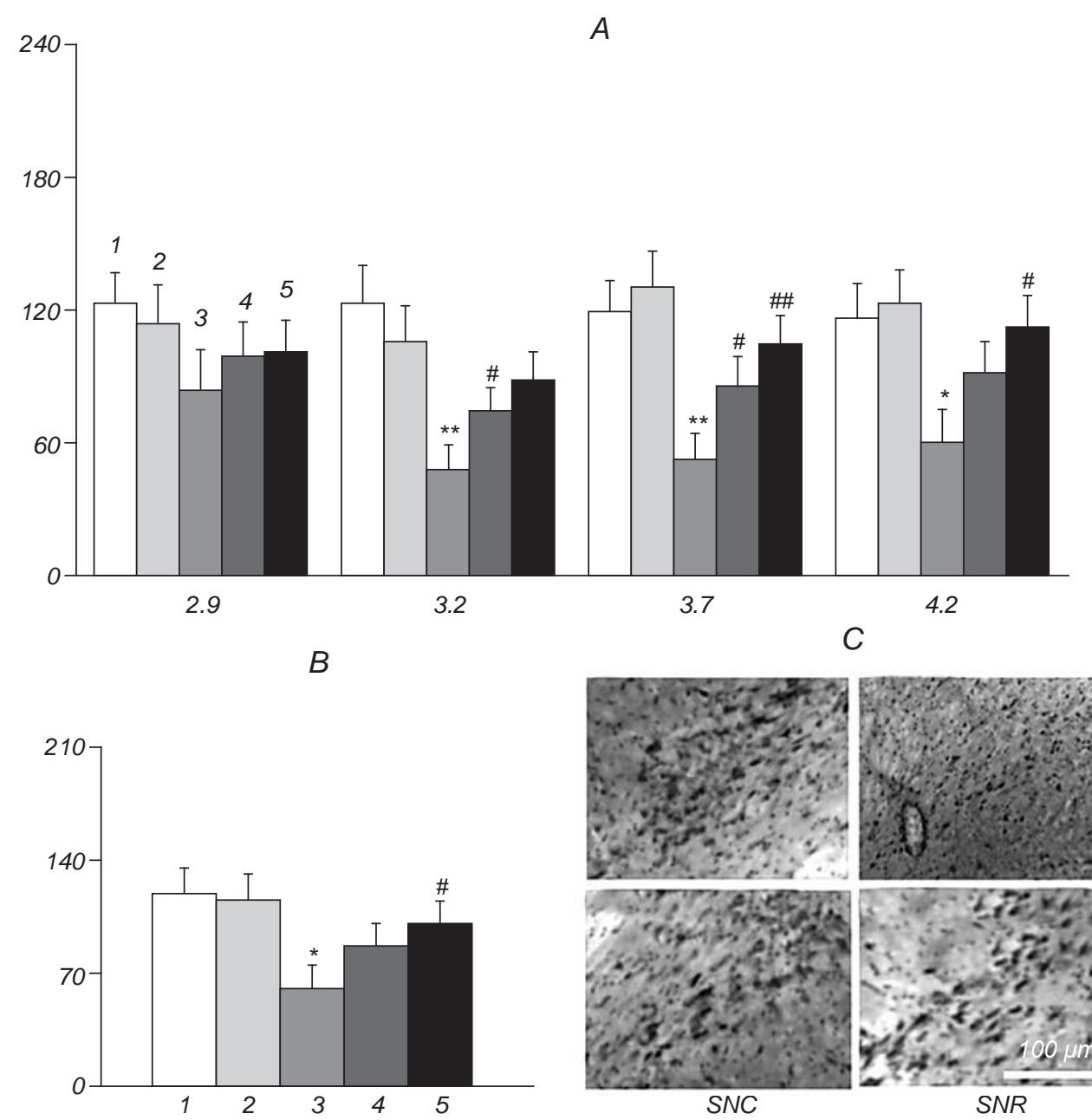

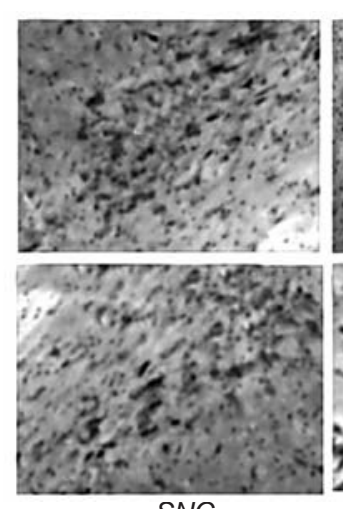

SNC

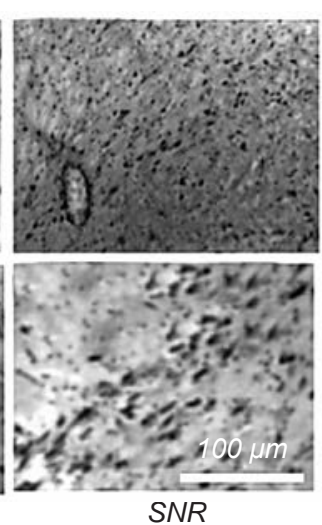

F i g. 2: Total numbers of Nissl-stained neurons on the left side of the substantia nigra within different frontal planes (A), averaged numbers of such units in all planes (B), and photomicrographs of the substantia nigra (C) one week after 6-ODHA introduction. SNC and SNR are substantia nigra pars compacta and substantia nigra pars reticulate, respectively. $* P<0.05$, ** $P<0.01$ in comparisons with the sham group; ${ }^{\#} P<0.05$, \# $P<0.01$ in comparison with the 6-OHDA group with no trigonelline. Designations of the groups are similar to those in Fig. 1.

Р и с. 2. Кількості забарвлених, за Ніслем, нейронів у лівій частині компактної зони чорної субстанції (SNC) у тварин різних експериментальних груп.

Findings of Nissl staining (Fig. 2) showed that there was no significant difference between the sham and sham+trigonelline(100) groups regarding the number of Nissl-stained neurons within the left SNC side. In addition, a significant reduction was noticed in the $6-O H D A-l e s i o n e d$ group $(P<0.05)$. There were no significant reductions in the 6-OHDA+trigonelline(50) and 6-OHDA+trigonelline(100) groups when compared to the sham group. In this respect, the number of Nissl-stained neurons on the left side of SNC was significantly higher in the 6-OHDA+trigonelline (100) group vs. the 6-OHDA-lesioned group $(P<0.05)$.

With respect to biochemical markers of oxidative stress (Fig. 3), 6-OHDA-lesioned rats demonstrated a significant elevation of the MDA content $(P<0.05)$ and nitrite amount $(P<0.05)$, as well as reduction of the GSH level $(P<0.05)$. At the same time, there was no significant reduction of the activity of the defensive enzyme (catalase) vs. the respective index in the sham group. The treatment of lesioned rats with trigonelline at a dose of $100 \mathrm{mg} / \mathrm{kg}$ significantly lowered only the MDA content $(P<0.05)$. Meanwhile, there were no significant changes in the trigonelline(100)-treated sham group relatively to sham animals regarding these parameters. Furthermore, the measurement of chromosomal breakdown of DNA (which is a 

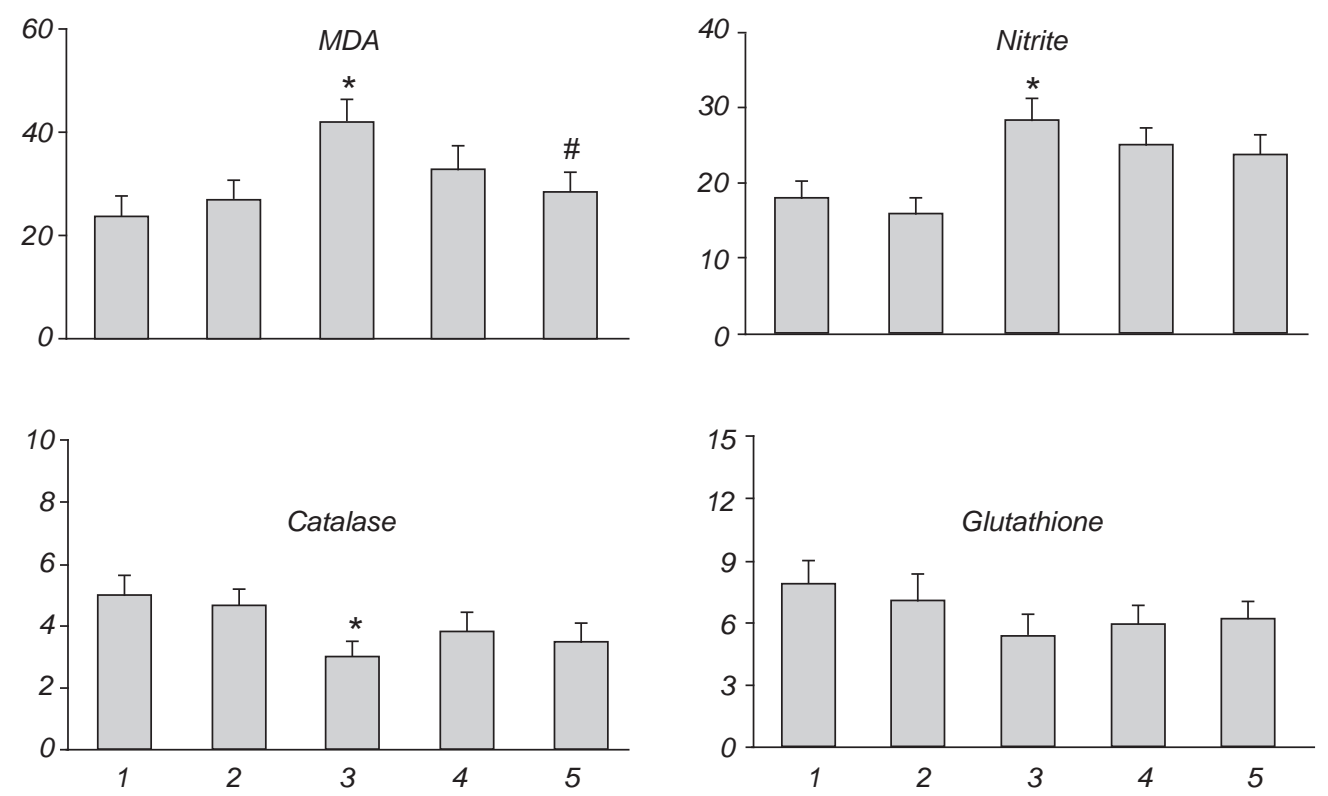

F i g. 3. Effects of trigonelline on midbrain oxidative stress markers. ${ }^{*} P<0.05$ in comparisons with the sham group; ${ }^{\#} P<0.05$ in comparison with the 6-OHDA group with no trigonelline. Designations of the groups are similar to those in Fig. 1.

Р и с. 3. Маркери оксидативного стресу в середньому мозку тварин різних експериментальних груп.

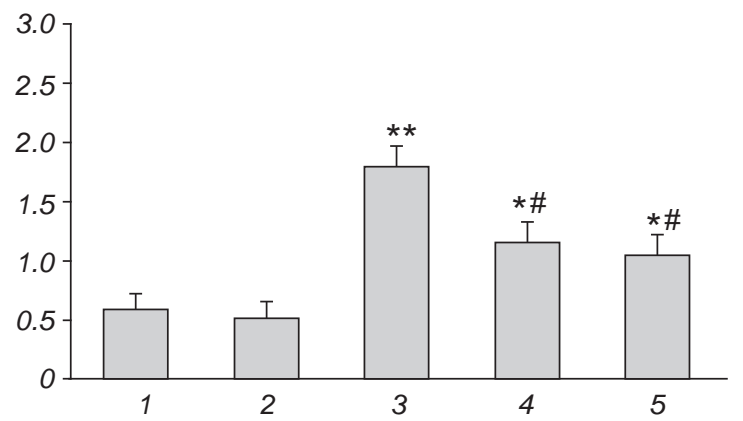

Fi g. 4. The effect of trigonelline on DNA fragmentation in 6-OHDAlesioned rat. $* P<0.05$ in comparisons with the sham group; ${ }^{\#} P<0.05$ in comparison with the 6-OHDA group with no trigonelline. Designations of the groups are similar to those in Fig. 1.

P и с. 4. Вплив попередніх уведень тригонелліну на інтенсивність фрагментації ДНК у моделі хвороби Паркінсона, індукованій 6-OHDA.

reliable indicator of apoptosis) showed a significant increase of DNA fragmentation in 6-OHDA-lesioned rats $(P<0.005)$ vs. the sham group. The trigonelline pretreatment at a dose of $100 \mathrm{mg} / \mathrm{kg}$ significantly reduced this index in comparison to that in the 6-OHDA group $(P<0.05)$, as is shown in Fig. 4 .

\section{DISCUSSION}

In our study, we confirmed that trigonelline pretreatment in the $100 \mathrm{mg} / \mathrm{kg}$ daily dose significantly reduces apomorphine-induced rotations in the respective model, increases the viability of SNC neurons, prevents their apoptosis, and restores the MDA level in 6-OHDAlesioned rats.

Selective degeneration of dopaminergic neurons in patients with $\mathrm{PD}$ results from a genetically and/or environmentally-induced process of the neurodegeneration (mostly in the SNC) [23]. 6-OHDA, the agent generally used for PD induction in rodent models, is assumed to cause selective degeneration of dopaminergic neurons in this structure [24]. The unilateral damage of the nigro-striatal dopaminergic system, induced by intrastriatal injection of 6-OHDA, is followed by a reduction in the striatal dopamine level and upregulation of dopaminergic postsynaptic receptors at the same side. These changes produce a prominent functional and motor asymmetry that can be evaluated by direct-acting dopaminergic agonists, apomorphine in particular [25]. These rotations are considered reliable indicators of nigro-striatal dopamine depletion [26]. In our study, significant attenuation of apomorphine-induced rotational 
behavior was observed in trigonelline(100)-pretreated 6-OHDA-lesioned rats. The observed attenuation of rotational behavior in the mentioned group could be attributed to a clear neuroprotective effect of trigonelline against SNC neurodegeneration and maintenance of striatal dopamine at a level that was not accompanied with a marked rotational behavior. In other words, nigro-striatal neurons within a SNC were mainly preserved in the presence of trigonelline against neurodegenerative effects induced by the neurotoxin 6-OHDA. In agreement with our earlier observations, a standardized hydroalcoholic extract of Trigonella foenum-graecum seeds, which contains considerable amounts of trigonelline, was capable of significantly lowering the intensity of induced rotations in unilaterally 6-OHDA-lesioned rats and to reverse motor dysfunctions, including enhanced spontaneous motor activity in 4-phenyl-1,2,3,6tetrahydropyridine-induced lesioned mice. These effects have been attributed to the neuroprotective potential of this mean [15].

In addition, an overproduction of free radicals, especially of reactive oxygen species, is also considerably involved in 6-OHDA-induced neurodegeneration [26]. Oxidative stress is among most important factors affecting the survival of dopaminergic neurons in PD. Neurons crucially depend on adequate energy supply produced by mitochondria and are simultaneously faced with high levels of reactive oxygen species, as well with increased levels of free iron. The latter phenomenon can promote hydroxyl production [27]. Overloading by the free radicals inevitably leads to intensification of the process of cell death. In addition, autooxidation of dopamine may produce dopamine quinine [28]. The formation of such species (semiquinones and other free radicals) can especially intensely damage nucleic acids, proteins, and membrane lipid components [29]. Therefore, the adequate therapeutic approaches should be aimed at attenuation of oxidative stress. Free radical scavengers may also be helpful in prolonging the survival time of dopaminergic neurons [30]. In this respect, trigonelline has been demonstrated to attenuate neuronal damage and to strongly counteract oxidative stress. The measurement of oxidative stress markers in our study also showed that trigonelline is able to attenuate this stress and to augment the antioxidant defensive system in the midbrain. In this way, this compound can significantly decrease the toxicity of 6-OHDA. This finding is consistent with literature data on the antioxidant ability of this mean via regulating the antioxidant defense system, as well as via suppression of free radical generation [11].

The inflammatory process initiated in the brain structures is also an important causative factor for PD [31, 32]. Pro-inflammatory cytokines released from glial cells can considerably stimulate nitric oxide production and exert a deleterious effect on dopaminergic neurons by activating receptors that contain intra-cytoplasmic death domains involved in the apoptotic pathway [33]. It has been shown that coffee (a food product that also contains high amounts of trigonelline) demonstrates noticeable anti-inflammatory activity [11]. Thus, it is possible that trigonelline may also lowered the level of the respective "PD-related" inflammatory mediators within the brain, and this also contributes in some a way to neuroprotection in 6-OHDA-induced PD model in rats, as was observed in our study. In addition, apoptosis is another factor that plays a critical role when cells are exposed to neurotoxins, including 6-OHDA [34]. In our study, trigonelline was able to prevent apoptosis, as evidenced by a lower DNA fragmentation. The anti-apoptotic effect of trigonelline has also been reported before [35]. Nevertheless, some aspects of the respective issue need further investigation.

Taken together, our results demonstrated that prelesion treatment with trigonelline in the animal model of PD exert, in a dose-dependent manner, clear neuroprotective and antiapoptotic effects against 6-OHDA toxicity. Henceforth, the above agent may be included in a set of therapeutic means advantageous for the management of early PD.

Acknowledgements. This research study was the result of MD thesis project approved and financially supported by the Shahed University in 2013.

The used procedures for animals and their care were in accordance with the existing international ethic norms for experimental work mentioned in the NIH guidelines.

The authors, M. Mirzaie, M. Khalili, Z. Kiasalari, and M. Roghani, confirm that they have no conflicts with respect to any kind related to commercial or financial problems, relations with organizations or persons, which could in any way be associated with the investigation, and with the relationship of the co-authors of the article. 
M. Мірзайє ${ }^{1,2}$, М. Халілі ${ }^{1}$, 3. Кіасаларі ${ }^{1}$, M. Рогані ${ }^{1}$

\section{НЕЙРОПРОТЕКТОРНИЙ ТА АНТИАПОПТОТИЧ- НИЙ ВПЛИВИ ТРИГОНЕЛЛІНУ В СТРІАТНІЙ МОДЕЛІ ХВОРОБИ ПАРКІНСОНА У ЩУРІВ, ІНДУКОВАНІЙ 6-ГІДРОКСИДОФАМІНОМ}

\author{
1,2 Нейрофізіологічний науково-дослідницький центр \\ Університету Шахед, Тегеран (Іран). \\ ${ }^{2}$ Студентський дослідницький комітет Університету Ша- \\ хед, Тегеран (Іран). \\ P е 3 ю м е
}

Беручи до уваги нейропротекторний та антиоксидантний вплив тригонелліну, ми дослідили його захисну дію в моделі хвороби Паркінсона у щурів, індукованій стереотаксичним уведенням 6-гідроксидофаміну (6-OHDA). Щурам, котрим робили унілатеральні ін'єкції 6-OHDA в стріатум, попередньо щоденно тричі вводили тригонеллін у дозах 50 i 100 мг/кг. В умовах використаної 6-OHDA-моделі істотно посилювалась обертальна моторна поведінка, викликана ін'єкцією апоморфіну, значно знижувалася кількість забарвлених, за Ніслем, нейронів у лівій половині компактної частини чорної субстанції, посилювався процес апоптозу нейронів, зростали рівні малональдегіду та нітриту та знижувався рівень відновленого глутатіону. Тригонеллін у щоденних дозах 100 мг/кг вірогідно знижував кількість обертальних рухів, протидіяв зменшенню числа нейронів у чорній субстанції та розвитку апоптозу, а також нормалізував рівень малональдегіду. Отримані результати свідчать про те, що уведення тригонелліну перед ін'єкціями 6-OHDA забезпечує дозозалежні нейропротекторний та антиапоптотичні ефекти в умовах токсичної дії 6-OHDA. Цей агент та його аналоги можуть бути тестовані як допоміжні засоби при лікуванні хвороби Паркінсона на ранніх стадіях.

\section{REFERENCES}

1. J. Massano and K. P. Bhatia, "Clinical approach to Parkinson's disease: features, diagnosis, and principles of management," Cold Spring Harb. Perspect. Med., 2, No. 6, a008870 (2012).

2. K. Wirdefeldt, H. O. Adami, P. Coleand, et al., "Epidemiology and etiology of Parkinson's disease: a review of the evidence," Eur. J. Epidemiol., 26, Suppl. 1, S1-S58 (2011).

3. H. S. Lindgren and S. B. Dunnett, "Cognitive dysfunction and depression in Parkinson's disease: what can be learned from rodent models?" Eur. J. Neurosci., 35, No. 12, 1894-1907 (2012).

4. A. Reeve, E. Simcox, and D. Turnbull, "Ageing and Parkinson's disease: Why is advancing age the biggest risk factor?" Ageing Res. Rev., 14C, 19-30 (2014).

5. T. Foltynie and J. Kahan, "Parkinson's disease: an update on pathogenesis and treatment," J. Neurol., 260, No. 5, 1433-1440 (2013).

6. C. Ossig and H. Reichmann, "Treatment of Parkinson's disease in the advanced stage," J. Neural Transm., 120, No. 4, 523-529 (2013).
7. T. Baluchnejadmojarad, M. Roghani, and M. Mafakheri, "Neuroprotective effect of silymarin in 6-hydroxydopamine hemi-parkinsonian rat: involvement of estrogen receptors and oxidative stress," Neurosci. Lett., 480, No. 3, 206-210 (2010).

8. M. Roghani, A. Niknam, M. R. Jalali-Nadoushanand, et al., "Oral pelargonidin exerts dose-dependent neuroprotection in 6-hydroxydopamine rat model of hemi-parkinsonism," Brain Res. Bull., 82, Nos. 5/6, 279-283 (2010).

9. S. E. Seidl, J. A. Santiago, H. Bilykand, et al., "The emerging role of nutrition in Parkinson's disease," Front. Aging Neurosci., 6, 36 (2014).

10. S. V. More, H. Kumar, S. M. Kangand, et al., "Advances in neuroprotective ingredients of medicinal herbs by using cellular and animal models of Parkinson's disease," Evid. Based Complement. Alternat. Med., 2013, 957875 (2013).

11. O. Yoshinari, A. Takenake, and K. Igarashi, "Trigonelline ameliorates oxidative stress in type 2 diabetic Goto-Kakizaki rats," J. Med. Food, 16, No. 1, 34-41 (2013).

12. W. J. Yen, B. S. Wang, L. W. Changand, et al., "Antioxidant properties of roasted coffee residues," J. Agric. Food Chem., 53, No. 7, 2658-2663 (2005)

13. B. N. Hong, T. H. Yi, S. Y. Kimand, et al., "High-dosage pyridoxine-induced auditory neuropathy and protection with coffee in mice," Biol. Pharm. Bull., 32, No. 4, 597-603 (2009).

14. C. Tohda, T. Kuboyama, and K. Komatsu, "Search for natural products related to regeneration of the neuronal network," Neurosignals, 14, Nos. 1/2, 34-45 (2005).

15. V. Gaur, S. L. Bodhankar, V. Mohanand, et al., "Neurobehavioral assessment of hydroalcoholic extract of Trigonella foenum-graecum seeds in rodent models of Parkinson's disease," Pharm. Biol., 51, No. 5, 550-557 (2013).

16. G. Paxinos and C. Watson, The Rat Brain in Stereotaxic Coordinates, Acad. Press, San Diego (1986).

17. T. Baluchnejadmojarad and M. Roghani, "Chronic epigallocatechin-3-gallate ameliorates learning and memory deficits in diabetic rats via modulation of nitric oxide and oxidative stress," Behav. Brain Res., 224, No. 2, 305-310 (2011).

18. A. Claiborne, "Catalase activity," in: CRC Handbook of Methods for Oxygen Radical Research, R. A. Greenwald (ed.), Boca Raton (1985), pp. 283-284.

19. J. Sedlak and R. H. Lindsay, "Estimation of total, proteinbound, and nonprotein sulfhydryl groups in tissue with Ellman's reagent," Anal. Biochem., 25, No. 1, 192-205 (1968).

20. G. L. Ellman, "Tissue sulfhydryl groups," Arch. Biochem. Biophys., 82, No. 1, 70-77 (1959).

21. M. M. Bradford, "A rapid and sensitive method for the quantitation of microgram quantities of protein utilizing the principle of protein-dye binding," Anal. Biochem., 72, 248-254 (1976)

22. S. Afshin-Majd, M. Khalili, M. Roghaniand, et al., "Carnosine exerts neuroprotective effect against 6-hydroxydopamine toxicity in hemiparkinsonian rat," Mol. Neurobiol. 51, No. 3, 1064-1070 (2014).

23. V. P. Chou, N. Ko, T. R. Holmanand, et al., "Gene-environment interaction models to unmask susceptibility mechanisms in Parkinson's disease," J. Vis. Exp., 83, e50960. doi: 10.3791/50960. (2014)

24. A. Schober, "Classic toxin-induced animal models of Parkinson's disease: 6-OHDA and MPTP," Cell Tissue Res., 318, No. 1, 215-224 (2004).

25. R. K. Schwarting and J. P. Huston, "Behavioral and 
neurochemical dynamics of neurotoxic meso-striatal dopamine lesions," Neurotoxicology, 18, No. 3, 689-708 (1997).

26. M. Jalali-Nadoushan and M. Roghani, "Alpha-lipoic acid protects against 6-hydroxydopamine-induced neurotoxicity in a rat model of hemi-parkinsonism," Brain Res., 1505, 68-74 (2013).

27. P. Foley and P. Riederer, "Influence of neurotoxins and oxidative stress on the onset and progression of Parkinson's disease," J. Neurol., 247, Suppl. 2, 1182-1194 (2000).

28. J. Lotharius and P. Brundin, "Pathogenesis of Parkinson's disease: dopamine, vesicles and alpha-synuclein," Nat. Rev. Neurosci., 3, No. 12, 932-942 (2002).

29. O. von Bohlen und Halbach, A. Schober, and K. Krieglstein, "Genes, proteins, and neurotoxins involved in Parkinson's disease," Prog. Neurobiol., 73, No. 3, 151-177 (2004).

30. S. Chen and W. Le, "Neuroprotective therapy in Parkinson disease," Am. J. Ther., 13, No. 5, 445-457 (2006).

31. F. Zhou, J. Y. Wu, X. L. Sunand, et al., "Iptakalim alleviates rotenone-induced degeneration of dopaminergic neurons through inhibiting microglia-mediated neuroinflammation," Neuropsychopharmacology, 32, No. 12, 2570-2580 (2007).

32. J. Miklossy, D. D. Doudet, C. Schwaband, et al., "Role of ICAM-1 in persisting inflammation in Parkinson disease and MPTP monkeys," Exp. Neurol., 197, No. 2, 275-283 (2006).

33. K. Sriram and J. P. O'Callaghan, "Divergent roles for tumor necrosis factor-alpha in the brain," J. Neuroimmune Pharmacol., 2, No. 2, 140-153 (2007).

34. C. K. Hwang and H. S. Chun, "Isoliquiritigenin isolated from licorice Glycyrrhiza uralensis prevents 6-hydroxydopamineinduced apoptosis in dopaminergic neurons," Biosci. Biotechnol. Biochem., 76, No. 3, 536-543 (2012).

35. A. E. Ghule, S. S. Jadhav, and S. L. Bodhankar, "Trigonelline ameliorates diabetic hypertensive nephropathy by suppression of oxidative stress in kidney and reduction in renal cell apoptosis and fibrosis in streptozotocin induced neonatal diabetic (nSTZ) rats," Int. Immunopharmacol., 14, No. 4, 740748 (2012). 